\title{
Efficacy and residual effect of Illicium verum (star anise) and Pelargonium graveolens (rose geranium) essential oil on cat fleas Ctenocephalides felis felis
}

\author{
Eficácia e efeito residual dos óleos essenciais de Illicium verum (anis-estrelado) e \\ Pelargonium graveolens (gerânio rosa) em pulgas de gato Ctenocephalides felis felis
}

\author{
Juliana Pereira Freitas'; Ingrid Lins Raquel de Jesus'; Jéssica Karoline de Oliveira Chaves'; Isabela Scalioni \\ Gijsen'; Diefrey Ribeiro Campos ${ }^{1 *}$ (1); Debora Pereira Baptista2; Thais Paes Ferreira1; Melina Cardilo Campos \\ Alves ${ }^{1}$; Katherina Coumendouros ${ }^{1}$; Yara Peluso Cid ${ }^{1,2}$; Douglas Siqueira de Almeida Chaves 1,2 \\ 'Programa de Pós-graduação em Ciências Veterinárias, Instituto de Veterinária, Universidade Federal Rural do Rio de Janeiro - UFRRJ, \\ Seropédica, RJ, Brasil \\ ²Programa de Pós-graduação em Química, Instituto de Química, Universidade Federal Rural do Rio de Janeiro -- UFRRJ, Seropédica, RJ, \\ Brasil
}

How to cite: Freitas JP, Jesus ILR, Chaves JKO, Gijsen IS, Campos DR, Baptista DP, et al. Efficacy and residual effect of IIlicium verum (star anise) and Pelargonium graveolens (rose geranium) essential oil on cat fleas Ctenocephalides felis felis. Braz J Vet Parasitol 2021; 30(4): e009321. https://doi.org/10.1590/S1984-29612021088

\begin{abstract}
The essential oils (EOs) of Illicium verum and Pelargonium graveolens were evaluated for lethality, inhibition of development and residual efficacy against the flea Ctenocephalides felis felis. Their chemical composition was characterized by means of gas chromatography with a flame ionization and mass spectrometry detection. Mortality at different immature stages and among adult fleas was measured through in vitro filter paper tests at different concentrations of EOs. The chemical characterization of I. verum volatile oil showed that $E$-anethole (79.96\%) was the major constituent, while the major compounds in P. graveolens were citronellol (29.67\%) and geraniol (14.85\%). Insecticidal activity against both immature and adult flea stages were observed. The EO of $I$. verum had insecticidal activity for approximately 18 days, while the EO activity of $P$. graveolens lasted for 13 days. The pulicidal activity of $I$. verum remained above $70 \%$ for up to 9 days, while the activity of $P$. graveolens was $41.7 \%$ for up to 2 days. Essential oils, especially that of $I$. verum, showed insecticidal activity for flea control at different life cycle stages and have potential for the development of ectoparasiticides (biopesticides) for veterinary use.
\end{abstract}

Keywords: Flea, volatile oil, phenylpropanoid, terpenes, geranium, gas chromatography.

\section{Resumo}

Os óleos essenciais (OE) de Illicium verum e Pelargonium graveolens foram avaliados quanto à letalidade, inibição do desenvolvimento e eficácia residual contra a pulga Ctenocephalides felis felis. Sua composição química foi caracterizada por meio de cromatografia gasosa com detector de ionização de chama e espectrometria de massas. A mortalidade entre os diferentes estágios imaturos e pulgas adultas foi avaliada por meio de testes in vitro em papel filtro, contendo diferentes concentrações de OEs. A caracterização química do óleo volátil de I. verum mostrou que o E-anetol $(79,96 \%)$ foi o constituinte majoritário, enquanto os principais compostos de $P$. graveolens foram citronelol (29,67\%) e geraniol (14,85\%). Foi observada atividade inseticida contra os estágios imaturos e adulto da pulga. O OE de I. verum teve atividade inseticida por aproximadamente 18 dias, enquanto o de $P$. graveolens durou 13 dias. A atividade pulicida de I. verum permaneceu acima de $70 \%$ até o $9^{\circ}$ dia, enquanto a atividade de $P$. graveolens foi de $41,7 \%$ até o $2^{\circ}$ dia. Os óleos essenciais, principalmente de $I$. verum, apresentam atividade inseticida para o controle de pulgas em diferentes estágios do ciclo de vida e têm potencial para o desenvolvimento de ectoparasiticidas (biopesticidas) de uso veterinário.

Palavras-chave: Pulga, óleo volátil, fenilpropanóide, terpenos, gerânio, cromatografia gasosa.

Received May 23, 2021. Accepted September 29, 2021.

*Corresponding author: Diefrey Ribeiro Campos. E-mail: diefrey8@gmail.com

This is an Open Access article distributed under the terms of the Creative Commons Attribution License, which permits unrestricted use distribution, and reproduction in any medium, provided the original work is properly cited. 


\section{Introduction}

Ownership of pets such as dogs and cats is increasing, causing rising concern over methods to control infestations caused by ectoparasites such as fleas. Ctenocephalides felis felis is the most prevalent flea subspecies parasitizing companion animals worldwide. They are responsible for causing blood loss and irritation of parasitized animals (Rust, 2020). Saliva inoculation can lead to the development of flea allergy dermatitis, which represents a large part of dermatological care in dogs and cats (Streicher, 2019). Furthermore, they are responsible for the transmission of several pathogens such as: Bartonella species, Coxiella burnetii, Hemoplasmas, Rickettsia species and Yersinia pestis (Lappin et al., 2020).

Essential oil are complex mixtures originated from the secondary metabolism, produced by the glandular trichomes, and in different secretory structures. Then can be compose of terpenes (mainly mono and sesqui) and/ or phenylpropanoids. These can be applied by industry, food and pharmaceuticals (Dawood et al., 2021). Activity of essential oils against fleas has been reported (Lambert et al., 2020; Dos Santos et al., 2020; Conceição et al., 2020). It is believed that these oils can act by means of several mechanisms, since the chemical composition of essential oils is complex, possibly including mono and sesquiterpenes and/or phenylpropanoids.

Illicium verum, known as star anise, has shown activity against several insects of agricultural and veterinary importance (Matos et al., 2020). Its major compound is the phenylpropanoid E-anethole. Pelargonium graveolens, known as rose geranium, is also toxic to various insects (Saraiva et al., 2020). Its oil is rich in the monoterpenes citronellol and geraniol (Saraiva et al., 2020).

The aim of the present study was to conduct an in vitro evaluation on the insecticidal activity of the essential oils of star anise and rose geranium against the different immature stages and residual efficacy against the adult form of the flea Ctenocephalides felis felis.

\section{Material and Methods}

\section{Essential oils}

Essential oils of Illicium verum L. (Schisandraceae) (star anise) - and Pelargonium graveolens L'Hér. ex Aiton (Geraniaceae) (rose geranium) were purchased commercially (Via Aroma ${ }^{\odot}$ ). The EOs were kept protected from the light and were stored at $-20^{\circ} \mathrm{C}$ until the time of the chromatographic and biological analyses.

\section{Dereplication of chemical constituents}

The analysis was performed by means of a gas chromatography (GC) device equipped with a flame ionization detector (FID) and a split/split-less injector to separate and detect the constituents of the volatile oils of $I$. verum and $P$. graveolens. The compounds were separated using a fused silica capillary column (5\% phenyl; $95 \%$ dimethylpolysiloxane), of dimensions $30 \mathrm{~m} \times 0.25 \mathrm{~mm}$ (i.d.) $\times 0.25 \mu \mathrm{m}$ (film thickness). Helium was used as the carrier gas at a flow rate of $1 \mathrm{~mL} / \mathrm{min}$. The column temperature was programmed as follows: $60{ }^{\circ} \mathrm{C}$ for 2 min followed by heating at $5^{\circ} \mathrm{C} / \mathrm{min}$ to $110^{\circ} \mathrm{C}$, followed by heating at $3^{\circ} \mathrm{C} / \mathrm{min}$ to $150^{\circ} \mathrm{C}$ and, lastly, followed by heating at $15^{\circ} \mathrm{C} / \mathrm{min}$ up to $290{ }^{\circ} \mathrm{C}$ and holding this constant for $15 \mathrm{~min}$. The injector temperature was $220^{\circ} \mathrm{C}$ and the detector temperature was $290^{\circ} \mathrm{C}$. To separate and identify the substances, $1 \mu \mathrm{L}$ of volatile oils samples diluted in dichloromethane $(10 \mu \mathrm{l} / \mathrm{ml})$ was injected at the times defined, into the gas chromatograph coupled to a mass spectrometer (GC-MS) QP-2010 Plus (Shimadzu, Japan). The flow of the helium carrier gas, the capillary column and the temperature conditions for the GC-MS analysis were the same as described for the GC. The temperature of the injector was $220^{\circ} \mathrm{C}$ and the interface temperature was $250^{\circ} \mathrm{C}$. Mass spectra were obtained with a quadrupole detector operating at $70 \mathrm{eV}$, with a mass range of $40-400 \mathrm{~m} / \mathrm{z}$ and a scanning rate of $0.5 \mathrm{scan} / \mathrm{s}$.

The chemical identification of the essential oil was based on linear retention indices (LRI) and mass spectra of the samples. These were compared with authentic standards injected under the same conditions, and using the NIST database (2008) and the Kovats index (KI) (Adams, 2007). The LRI was calculated based on co-injection of alkane series (van Den Dool \& Kratz, 1963).

\section{Flea origin}

Different stages (adults, eggs, larvae and pupae) of Ctenocephalides felis felis (Bouché, 1935), obtained from a laboratory colony maintained in cats without introduction of external specimens and without exposure to 
insecticides since 1998, were used in this study. This species is registered in the National System of Genetic Heritage Management and Associated Traditional Knowledge (SisGen) under number A710DC4 and the flea colony was approved by the Ethics Committee for Animal Use of the Veterinary Institute, Federal Rural University of Rio de Janeiro, under protocol number 4313110419.

\section{Essential oil activity against Ctenocephalides felis felis in vitro}

The technique using filter paper was used for the bioassays. Dilutions of the essential oils of $I$. verum and $P$. graveolens were made using acetone as diluent and as a negative control. For positive control, a solution of fipronil ( $400 \mu \mathrm{g} . \mathrm{mL}^{-1}$ ) was used. Direct dilutions of the essential oil were made, to obtain 10 solutions at concentrations ranging from $40,000 \mu \mathrm{g} \cdot \mathrm{mL}^{-1}$ to $100 \mu \mathrm{g} \cdot \mathrm{mL}^{-1}$ for 1 . verum and from $12,000 \mu \mathrm{g} \cdot \mathrm{mL}^{-1}$ to $50 \mu \mathrm{g} \cdot \mathrm{mL}^{-1}$ for $P$. graveolens, according to the flea stage under analysis. The bioassays were performed in sextuplicate, with filter paper strips of $10 \mathrm{~cm}^{2}$ and filter paper discs of $23.76 \mathrm{~cm}^{2}$, for adult fleas and immature phases, respectively. The strips were impregnated with $200 \mu \mathrm{L}$ and the discs with $475 \mu \mathrm{L}$ of their respective dilutions, so that the final concentrations for I. verum and $P$. graveolens were in the range of 800.00 to $100.00 \mu \mathrm{g} . \mathrm{cm}^{-2}$ and 240.00 to $120.00 \mu \mathrm{g} . \mathrm{cm}^{-2}$ respectively. After impregnation, the tapes and discs were dried for $1 \mathrm{~h}$ before the bioassay procedure.

The in vitro activity of the essential oils against immature stages of $C$. felis felis was evaluated using filter paper tests against (Conceição et al., 2020) eggs, larvae and pupae. The inhibition of flea development was also analyzed. The dried impregnated discs were inserted in petri dishes containing 10 eggs, larvae or pupae of $C$. felis felis. After sealing, the petri dishes were kept in a climatized chamber (Eletrolab ${ }^{\circledR}$, Model: 102FC, Serie: 970603) at $28 \pm 1{ }^{\circ} \mathrm{C}$ and relative humidity of $75 \pm 10 \%$.

The evaluation criteria for ovicidal, larvicidal and pupicidal tests were the hatching, motility and emergence of adult fleas, respectively. In the evaluation of developmental inhibition, 10 newly collected eggs were incubated in a petri dish with the impregnated disc, and the emergence of adult fleas was evaluated. The results from the ovicidal test were evaluated after $72 \mathrm{~h}$, as was also the development inhibition test, the larvicidal test after 24 and $48 \mathrm{~h}$, while the pupicidal test was evaluated after 15 days. All tests were performed in sextuplicate.

In vitro insecticidal activity against $C$. felis felis adults was evaluated using the impregnated filter paper technique (Conceição et al., 2020) against unfed fleas obtained from the laboratory colony. The impregnated and dried strips were inserted into glass tubes containing 10 unfed adult cat fleas (five males and five females). After sealing with non-woven tissue and rubber bands, the tubes were kept in a climatized chamber at $28 \pm 1{ }^{\circ} \mathrm{C}$ and relative humidity of $75 \pm 10 \%$. Insecticidal activity was evaluated according to the motility of the fleas, which were deemed to be alive at the slightest movement observed. The tests were performed in sextuplicate for each concentration. The mean number of live adult fleas per concentration was evaluated after 24 and $48 \mathrm{~h}$ using a stereo microscope (Wild Heerbrugg, M5-52796).

\section{Efficacy evaluation and establishment of $\mathrm{LC}_{50}$ and $\mathrm{LC}_{90}$ and Statistical analysis}

To calculate the efficacy, Abbott's formula (Abbott, 1987) was used: percentage efficacy $=[($ mean number of fleas (corresponding flea stage) of the control group - mean number of fleas (corresponding flea stage) of the treated group)/ (mean number of fleas (corresponding flea stage) of the control group)] $\times 100 . \mathrm{LC}_{50}$ and LC $\mathrm{C}_{90}$ were established through Probit analysis using the RStudio Team software (2020, RStudio: Integrated Development Environment for R. RStudio, PBC, Boston, MA, USA). Statistical significance was set at $5 \%(P<0.05)$.

To compare the mortality means between the different concentrations, the Shapiro Wilks test was performed to determine the normality of the data. The comparison of means was performed using the ANOVA test followed by the T-test (LSD). The BioEstat version 5.3 program was used for the statistical analysis of the data, considering a significance level (a) $5 \%$.

\section{Residual efficacy}

The residual efficacy of the essential oils against adults of $C$. felis felis was assessed by means of the filter paper impregnation technique (Conceição et al., 2020) against unfed fleas. The impregnated and dried strips were inserted into glass tubes containing 10 unfed adult cat fleas (five males and five females). After sealing with non-woven tissue and rubber bands, the tubes were kept in a climatized chamber at $28 \pm 1{ }^{\circ} \mathrm{C}$ and relative humidity of $75 \pm 10 \%$. Every $24 \mathrm{~h}$, live fleas were counted and the fleas in the tubes were replaced with 10 new fleas. The impregnated 
tape was maintained to assess the durability of the insecticidal activity of the essential oils in a single application. The tests were performed in sextuplicate, using the concentration responsible for $100 \%$ mortality: $800 \mu g . \mathrm{cm}^{-2}$ and $240 \mu \mathrm{g} . \mathrm{cm}^{-2}$, for $I$. verum and $P$. graveolens, respectively. Insecticidal activity was evaluated according to the motility of the fleas, which were deemed to be alive at the slightest movement observed.

\section{Results}

\section{Chemical analysis}

The gas chromatography analysis (Table 1) led to identification of 15 compounds in I. verum EO, among which the phenylpropanoid (E)-anethole was the major compound (79.96\%) and the other constituents were in a concentration lower than 10\% (Figure 1a). In turn, the P. graveolens EO was found to contain 27 compounds, among which the major ones were the class of monoterpene oxygenated as citronellol (29.67\%) and geraniol (14.85\%) (Figure 1b).

\section{Efficacy and $\mathrm{LC}_{50}$ and $\mathrm{LC}_{90}$}

The essential oil of I. verum caused $100 \%$ mortality of adult fleas at a concentration of $400.0 \mu \mathrm{g} . \mathrm{cm}^{-2}$ after 48 hours. This same total mortality was observed for concentrations of $80.0 \mu \mathrm{g} . \mathrm{cm}^{-2}, 20.0 \mu \mathrm{g} . \mathrm{cm}^{-2}$ and $140.0 \mu \mathrm{g} . \mathrm{cm}^{-2}$ against the egg, larval and pupal stages, respectively. The concentration of $40.0 \mu \mathrm{g} . \mathrm{cm}^{-2}$ totally inhibited development from egg to adult. In turn, the essential oil of $P$. graveolens caused $100 \%$ mortality at lower concentrations after exposure for 48 hours: $240.0 \mu \mathrm{g} . \mathrm{cm}^{-2}$ against adult fleas; $100.0 \mu \mathrm{g} . \mathrm{cm}^{-2}$ against pupae; and $35.0 \mu \mathrm{g} . \mathrm{cm}^{-2}$ for inhibition of the biological cycle. On the other hand, the concentrations causing $100 \%$ mortality were greater for ovicidal activity $\left(60.0 \mu \mathrm{g} . \mathrm{cm}^{-2}\right)$ and larvicidal activity $\left(40.0 \mu \mathrm{g} . \mathrm{cm}^{-2}\right)$ (Table 2$)$.

Comparison of the estimated lethal concentration values revealed that the immature stages were more susceptible when measured using the $\mathrm{LC}_{50}$ values, ranging from 7.9 to $12.4 \mu \mathrm{g} . \mathrm{cm}^{-2}$ for inhibition of the biological cycle, 18.8 to $36.9 \mu \mathrm{g} . \mathrm{cm}^{-2}$ against eggs, 12.1 to $16.3 \mu \mathrm{g} . \mathrm{cm}^{-2}$ versus larvae, and 35.4 to $67.6 \mu \mathrm{g} . \mathrm{cm}^{-2}$ against pupae. The same pattern was observed for the estimated $L C_{90}$ values, ranging from 20.4 to $30.1 \mu \mathrm{g} \cdot \mathrm{cm}^{-2}$ for inhibition of the biological cycle, 54.5 to $55.6 \mu \mathrm{g} . \mathrm{cm}^{-2}$ against eggs, 16.8 to $32.3 \mu \mathrm{g} . \mathrm{cm}^{-2}$ against larvae and 85.4 to $87.9 \mu \mathrm{g} . \mathrm{cm}^{-2}$ versus pupae. Both essential oils presented similar $\mathrm{LC}_{50}$ and $\mathrm{LC}_{90}$ values for inhibition of the biological cycle and egg stage, while for larvicidal activity, the I. verum essential oil presented relative potency $\left(\mathrm{LC}_{90}\right) 2$-fold higher. For adult fleas, the insecticidal activities measured by $\mathrm{LC}_{50}$ and $\mathrm{LC}_{90}$ ranged from 119.1 to $164.6 \mu \mathrm{g} \cdot \mathrm{cm}^{-2}$ and from 209.5 to $258.1 \mu \mathrm{g} . \mathrm{cm}^{-2}$, respectively (Table 3 ).

\section{Residual efficacy}

The residual efficacy of the essential oils was measured to assess the longevity of insecticidal activity (Figure $2 \mathrm{a}$ and $2 \mathrm{~b}$ ). The EO of $I$. verum retained its insecticidal activity for approximately 18 days, while the $\mathrm{OE}$ activity of $P$. graveolens lasted for 13 days. The EO of $I$. verum caused $80 \%$ mortality on the $7^{\text {th }}$ day of exposure, decreasing to approximately $50 \%$ on the $10^{\text {th }}$ day of analysis. On the $13^{\text {th }}$ day, it was still able to kill $36.7 \%$ of the fleas and this went down to $1.7 \%$ activity on the $18^{\text {th }}$ day. Although the EO of Pelargonium graveolens had the lowest concentration capable of causing $100 \%$ mortality, its effectiveness did not last long. On the $3^{\text {rd }}$ day of exposure, the pulicidal activity of the $P$. graveolens EO declined to approximately $50 \%$ mortality, falling to just under $30 \%$ on the $5^{\text {th }}$ day, $9.5 \%$ on the $12^{\text {th }}$ day and no activity on the $13^{\text {th }}$ day of exposure.

\section{Discussion}

This is the first study to show the insecticidal activity of essential oils from I. verum and $P$. graveolens against adult fleas and their immature stages, as well as their residual activity. The chromatographic analysis showed a total of 16 substances in I. verum and 27 in P. graveolens. GC/MS identified that monoterpenes were the major class in $P$. graveolens (63.01\%) and phenylpropanoids formed the majority in I. verum (86.34\%). As described by other authors, $E$-anethole (1) was the major compound of star anise essential oil, but other phenylpropanoids, such as (Z)-anethole (2) and estragole (3), were also abundant (Yu et al., 2021). E-anethole has already been described as the major constituent of I. verum essential oil in some studies that report insecticidal activity (Nilprapat et al., 
Table 1. Chemical characterization of Illicium verum and Pelargonium graveolens essential oils.

\begin{tabular}{|c|c|c|c|}
\hline Compounds & AIT & IVEO & PGEO \\
\hline \multicolumn{4}{|l|}{ Monoterpenes hydrocarbons } \\
\hline a-pinene & 932 & 0.97 & - \\
\hline a-phellandrene & 1002 & 0.57 & - \\
\hline Carene & 1008 & 0.36 & - \\
\hline Limonene & 1024 & 2.05 & 0.80 \\
\hline$\beta$-phellandrene & 1025 & 0.43 & - \\
\hline \multicolumn{4}{|l|}{ Monoterpenes oxygenated } \\
\hline 1,8-cineol & 1026 & 0.42 & - \\
\hline Linalool & 1095 & - & 5.00 \\
\hline$(E)$-rose oxide & 1122 & - & 2.58 \\
\hline$\beta$-terpineol & 1140 & 3.58 & - \\
\hline$(+)$-menthone & 1148 & - & 2.50 \\
\hline (-)-menthone & 1148 & - & 5.72 \\
\hline 4-terpineol & 1174 & 0.29 & - \\
\hline a-terpineol & 1186 & - & 1.29 \\
\hline Citronellol & 1223 & - & 29.67 \\
\hline Neral & 1235 & - & 0.77 \\
\hline Geraniol & 1249 & - & 14.85 \\
\hline Geranial & 1264 & - & 0.45 \\
\hline Citronellyl formate & 1271 & - & 9.41 \\
\hline Neryl formate & 1280 & - & 4.13 \\
\hline \multicolumn{4}{|l|}{ Sesquiterpenes hydrocarbons } \\
\hline a-cubebene & 1348 & - & 0.40 \\
\hline Ylangene & 1373 & 0.31 & - \\
\hline a-ylangene & 1375 & - & 0.96 \\
\hline$\beta$-elemene & 1389 & - & 0.34 \\
\hline (Z)-farnesene & 1440 & - & 3.37 \\
\hline 6,9-guaiadiene & 1442 & - & 1.62 \\
\hline (E)-Muurola-3.5-diene & 1451 & - & 0.71 \\
\hline a-clovene & 1452 & - & 0.55 \\
\hline a-humulene & 1452 & - & 0.35 \\
\hline \multicolumn{4}{|l|}{ Sesquiterpenes oxygenated } \\
\hline$\beta$-thujaplicin & 1475 & 0.39 & - \\
\hline Geranyl propanoate & 1476 & - & 2.02 \\
\hline y-himachalene & 1481 & 1.20 & - \\
\hline Citronellyl butanoate & 1532 & - & 0.84 \\
\hline 2-phenyl ethyl tiglate & 1584 & - & 1.86 \\
\hline y-eudesmol & 1630 & - & 2.32 \\
\hline a-eudesmol & 1637 & - & 0.48 \\
\hline Citronellyl angelate & 1656 & - & 0.66 \\
\hline Geranyl tiglate & 1696 & - & 1.65 \\
\hline \multicolumn{4}{|l|}{ Phenylpropanoid } \\
\hline Estragole & 1195 & 5.75 & - \\
\hline Anisaldehyde & 1247 & 2.49 & - \\
\hline (Z)-anethole & 1249 & 0.63 & - \\
\hline$(E)$-anethole & 1282 & 79.96 & - \\
\hline Monoterpenes hydrocarbons & & 4.38 & 1.98 \\
\hline Monoterpenes oxygenated & & 4.29 & 61.83 \\
\hline Sesquiterpenes hydrocarbons & & 1.51 & 8.30 \\
\hline Sesquiterpenes oxygenated & & - & 4.45 \\
\hline Phenylpropanoid & & 86.34 & - \\
\hline Total & & 95.92 & 95.75 \\
\hline
\end{tabular}

The chemical composition was analyzed by GC-MS and organized in the table by order of elution (EO) in the chromatographic column. The concentration (\%) was calculated based on the total area of the peak by GC-FID. Tabulated arithmetic index (AIT). Not detected (-). IVEO - IIlicium verum essential oil. PGEO - Pelargonium graveolens essential oil. 
a)<smiles>C/C=C/c1ccc(OC)cc1</smiles>

$(E)$-anethole<smiles>C=CCc1ccc(OC)cc1</smiles>

Estragole b)<smiles>CC(C)=CCCC(C)CCO</smiles>

Citronellol<smiles>CC(C)=CCCC(C)=CCO</smiles>

Geraniol<smiles>CC(C)=CCC[C@H](C)CCOC=O</smiles>

Citronelly formate

Figure 1. Major compounds identified in the (a) Illicium verum and (b) Pelargonium graveolens essential oil.

Table 2. Mortality (\%) and life cycle inhibition of Illicium verum and Pelargonium graveolens volatile oils against different stage of the flea.

\begin{tabular}{|c|c|c|c|c|c|c|c|c|c|c|c|}
\hline \multicolumn{12}{|c|}{ Illicium verum } \\
\hline \multirow{2}{*}{$\begin{array}{c}\text { Conc. } \\
\left(\mu \mathrm{g} . \mathrm{cm}^{-2}\right)\end{array}$} & Egg* & Conc. & $\begin{array}{l}\text { Larva } \\
\text { (24h) }\end{array}$ & $\begin{array}{l}\text { Larva } \\
(48 \mathrm{~h})\end{array}$ & \multirow{2}{*}{$\begin{array}{l}\text { Conc. } \\
\left(\mu \mathrm{g} . \mathrm{cm}^{-2}\right)\end{array}$} & Pupae* & \multirow{2}{*}{$\begin{array}{c}\text { Conc. } \\
\left(\mu \mathrm{g} \cdot \mathrm{cm}^{-2}\right)\end{array}$} & ID* & \multirow{2}{*}{$\begin{array}{c}\text { Conc. } \\
\left(\mu \mathrm{g} \cdot \mathrm{cm}^{-2}\right)\end{array}$} & \multirow{2}{*}{$\begin{array}{l}\text { Adult } \\
(24 \mathrm{~h})\end{array}$} & \multirow{2}{*}{$\begin{array}{l}\text { Adult } \\
(48 \mathrm{~h})\end{array}$} \\
\hline & $\begin{array}{l}\text { Mortality } \\
(\%)\end{array}$ & $\left(\mu \mathrm{g} \cdot \mathrm{cm}^{-2}\right)$ & \multicolumn{2}{|c|}{ Mortality (\%) } & & $\begin{array}{l}\text { Mortality } \\
(\%)\end{array}$ & & $\begin{array}{c}\text { Mortality } \\
(\%)\end{array}$ & & & \\
\hline Cont. neg. & $11.7^{\mathrm{a}} \pm 36.7$ & Cont. neg. & $0^{\mathrm{a}} \pm 0$ & $0^{\mathrm{a}} \pm 0$ & Cont. neg. & $13.3^{\mathrm{a}} \pm 12.1$ & Cont. neg. & $21.7^{a} \pm 11.7$ & Cont. neg. & $0^{a} \pm 0$ & $0^{\mathrm{a}} \pm 0$ \\
\hline Placebo & $15.0^{\mathrm{a}} \pm 10.5$ & Placebo & $0^{\mathrm{a}} \pm 0$ & $0^{a} \pm 0$ & Placebo & $13.3^{\mathrm{a}} \pm 11.6^{\mathrm{a}}$ & Placebo & $21.7^{a} \pm 10.6$ & Placebo & $0^{\mathrm{a}} \pm 0$ & $0^{\mathrm{a}} \pm 0$ \\
\hline 30.0 & $26.7^{\mathrm{a}} \pm 8.2$ & 10.0 & $21.7^{\mathrm{b}} \pm 11.7$ & $26.7^{b} \pm 10.3$ & 20.0 & $25.0^{\mathrm{b}} \pm 8.4$ & 2.0 & $4.3^{\mathrm{a}} \pm 7.5$ & 100.00 & $40.0^{\mathrm{b}} \pm 25.0$ & $41.7^{b} \pm 19.4$ \\
\hline 40.0 & $61.7^{b} \pm 14.7$ & 12.0 & $38.3^{b} \pm 11.7$ & $45.0^{b} \pm 5.5$ & 40.0 & $58.3^{b} \pm 24.0$ & 5.0 & $41.7^{\mathrm{b}} \pm 14.7$ & 200.00 & $75.0^{\mathrm{b}} \pm 21.8$ & $75.0^{b} \pm 18.7$ \\
\hline 50.0 & $78.3^{b} \pm 29.3$ & 14.0 & $53.3^{b} \pm 17.5$ & $75.0^{\mathrm{b}} \pm 22.4$ & 60.0 & $66.7^{\mathrm{b}} \pm 25.8$ & 10.0 & $78.3^{b} \pm 14.7$ & 240.00 & $85.0^{\complement} \pm 17.6$ & $85.0^{\complement} \pm 17.6$ \\
\hline 60.0 & $93.3^{c} \pm 8.2$ & 16.0 & $71.7^{\mathrm{b}} \pm 21.4$ & $80.0^{\mathrm{b}} \pm 46.4$ & 80.0 & $85.0^{c} \pm 10.5$ & 20.0 & $85.0^{c} \pm 16.4$ & 300.00 & $90.0^{\complement} \pm 11.0$ & $93.3^{c} \pm 5.2$ \\
\hline 70.0 & $98.3^{c} \pm 4.1$ & 18.0 & $86.7^{c} \pm 13.7$ & $95.0^{\complement} \pm 5.5$ & 100.0 & $93.3^{c} \pm 8.2$ & 30.0 & $95.0^{c} \pm 8.4$ & 400.00 & $96.7 \mp \pm 5.2$ & $100.00^{\complement} \pm 5.5$ \\
\hline 80.0 & $100.0^{\complement} \pm 0.0$ & 20.0 & $98.3^{c} \pm 4.1$ & $100.0^{\complement} \pm 0$ & 140.0 & $100.0^{`} \pm 0$ & 40.0 & $100.0^{\complement} \pm 0$ & 800.00 & $100.0^{\complement} \pm 0$ & $100.0^{\complement} \pm 0$ \\
\hline \multicolumn{12}{|c|}{ Pelargonium graveolens } \\
\hline \multirow{2}{*}{$\begin{array}{l}\text { Conc. } \\
\left(\mu \mathrm{g} . \mathrm{cm}^{-2}\right)\end{array}$} & Egg* & ionc & $\begin{array}{l}\text { Larva } \\
\text { (24h) }\end{array}$ & $\begin{array}{l}\text { Larva } \\
(48 \mathrm{~h})\end{array}$ & \multirow{2}{*}{$\begin{array}{c}\text { Conc. } \\
\left(\mu \mathrm{g} \cdot \mathrm{cm}^{-2}\right)\end{array}$} & Pupae* & \multirow{2}{*}{$\begin{array}{c}\text { Conc. } \\
\left(\mu \mathrm{g} \cdot \mathrm{cm}^{-2}\right)\end{array}$} & ID* & \multirow{2}{*}{$\begin{array}{l}\text { Conc. } \\
\left(\mu \mathrm{g} . \mathrm{cm}^{-2}\right)\end{array}$} & $\begin{array}{l}\text { Adult } \\
\text { (24h) }\end{array}$ & $\begin{array}{l}\text { Adult } \\
(48 \mathrm{~h})\end{array}$ \\
\hline & $\begin{array}{c}\text { Mortality } \\
(\%)\end{array}$ & & \multicolumn{2}{|c|}{ Mortality (\%) } & & $\begin{array}{c}\text { Mortality } \\
(\%)\end{array}$ & & $\begin{array}{c}\text { Mortality } \\
(\%)\end{array}$ & & \multicolumn{2}{|c|}{ Mortality (\%) } \\
\hline Cont. neg. & $11.7^{\mathrm{a}} \pm 10.6$ & Cont. neg. & $0^{\mathrm{a}} \pm 0$ & $0^{\mathrm{a}} \pm 0$ & Cont. neg. & $11.7^{\mathrm{a}} \pm 12.1$ & Cont. neg. & $11.7 \pm 7.5$ & Cont. neg. & $0^{\mathrm{a}} \pm 0$ & $0^{\mathrm{a}} \pm 0$ \\
\hline Placebo & $13.3^{\mathrm{a}} \pm 10.3$ & Placebo & $0^{\mathrm{a}} \pm 0$ & $0^{\mathrm{a}} \pm 0$ & Placebo & $13.3^{a} \pm 8.6$ & Placebo & $11.6 \pm 8.2$ & Placebo & $0^{\mathrm{a}} \pm 0$ & $0^{\mathrm{a}} \pm 0$ \\
\hline 10.00 & $26.7^{b} \pm 11.7$ & 11.6 & $15.0^{\mathrm{b}} \pm 10.5$ & $21.7^{\mathrm{b}} \pm 11.7$ & 50.0 & $36.7^{a} \pm 12.1$ & 1.0 & $4.8 \pm 7.5$ & 120.00 & $10.2^{\mathrm{b}} \pm 21.9$ & $13.2^{\mathrm{b}} \pm 22.2$ \\
\hline 20.00 & $55.0^{\mathrm{b}} \pm 12.1$ & 20.0 & $23.3^{\mathrm{b}} \pm 37.8$ & $33.3^{\mathrm{b}} \pm 13.7$ & 60.0 & $55.0^{\mathrm{b}} \pm 15.2$ & 10.0 & $28.7 \pm 9.8$ & 140.00 & $18.3^{b} \pm 13.3$ & $23.3^{b} \pm 16.3$ \\
\hline 30.00 & $60.0^{\mathrm{b}} \pm 10.5$ & 25.0 & $53.3^{b} \pm 10.3$ & $70.0^{\mathrm{b}} \pm 6.3$ & 70.0 & $70.0^{b} \pm 12.6$ & 20.0 & $63.7 \pm 16.7$ & 160.00 & $38.3^{b} \pm 11.7$ & $41.7^{b} \pm 14.7$ \\
\hline 40.00 & $75.0^{\mathrm{b}} \pm 11.0$ & 30.0 & $70.0^{\mathrm{b}} \pm 11.0$ & $86.7^{\complement} \pm 12.1$ & 80.0 & $83.3^{b} \pm 16.3$ & 25.0 & $75.1 \pm 8.9$ & 180.00 & $53.3^{b} \pm 17.5$ & $65.0^{\mathrm{b}} \pm 25.1$ \\
\hline 50.00 & $90.0^{c} \pm 5.5$ & 35.0 & $93.3^{c} \pm 8.2$ & $98.3^{c} \pm 4.1$ & 90.0 & $91.7^{c} \pm 7.1$ & 30.0 & $85.1 \pm 11.7$ & 200.00 & $70.0^{b} \pm 15.5$ & $83.3^{b} \pm 10.3$ \\
\hline 60.00 & $100.0^{\complement} \pm 0$ & 40.0 & $100.0^{\complement} \pm 0$ & $100.0^{c} \pm 0$ & 100.0 & $100.0^{\complement} \pm 0$ & 35.0 & $100.0 \pm 0$ & 240.00 & $96.7^{c} \pm 8.2$ & $100.0^{\circ} 0$ \\
\hline
\end{tabular}

${ }^{*}$ Corrected mortality. ID = inhibition of development; h hours; Conc. = concentration; Neg. Cont. = negative control. Note: ANOVA test followed by the T-test (LSD). Different letters a b c indicate statistical difference. 
Table 3. Lethal concentrations $\left[\mathrm{LC}_{50}\right.$ and $\left.\mathrm{LC}_{90}\left(\mu \mathrm{g} \cdot \mathrm{cm}^{-2}\right)\right]$ and slopes for Illicium verum and Pelargonium graveolens essential oils against different immature stages and adults of Ctenocephalides felis felis.

\begin{tabular}{|c|c|c|c|c|c|c|}
\hline \multirow{2}{*}{ Essential oil } & \multirow{2}{*}{ Flea stage } & \multicolumn{2}{|c|}{$(95 \% \mathrm{CI})$} & \multirow{2}{*}{ Slope (SE) } & \multirow{2}{*}{$\mathbf{R}^{2}$} & \multirow{2}{*}{$\chi^{2}$} \\
\hline & & $\mathrm{LC}_{50}\left(\mu \mathrm{g} \cdot \mathrm{cm}^{-2}\right)$ & $\mathrm{LC}_{90}\left(\mu \mathrm{g} \cdot \mathrm{cm}^{2}\right)$ & & & \\
\hline \multirow[t]{7}{*}{ IVEO } & Egg & 36.9 (33.4-39.9) & $55.6(51.1-62.8)$ & $7.20(0.4)$ & 0.953 & 0.900 \\
\hline & Larvae (24 h) & $14.4(13.5-15.3$ & $20.8(19.2-23.4)$ & $8.1(0.8)$ & 0.951 & 0.568 \\
\hline & Larvae (48 h) & $12.1(11.21-12.7)$ & $16.8(15.7-18.5)$ & $8.1(0.9)$ & 0.960 & 0.562 \\
\hline & Pupae & $35.4(29.1-41.1)$ & $87.9(75.2-108.4)$ & $3.2(0.3)$ & 0.958 & 0.707 \\
\hline & ID & $7.9(3.7-9.3)$ & $20.4(15.3-30.5)$ & $2.1(0.2)$ & 0.904 & 0.733 \\
\hline & Adult (24 h) & $\begin{array}{c}121.7(82.4- \\
152.1)\end{array}$ & $\begin{array}{c}290.6(230.5- \\
434.1)\end{array}$ & $3.8(0.4)$ & 0.757 & 0.067 \\
\hline & Adult (48 h) & $\begin{array}{c}119.1(65.4- \\
157.4)\end{array}$ & $\begin{array}{c}258.1(194.4- \\
494.1)\end{array}$ & $3.8(0.6)$ & 0.955 & 0.750 \\
\hline \multirow[t]{7}{*}{ PGEO } & Egg & $18.8(14.9-22.4)$ & $54.5(44.1-75.6)$ & $2.8(0.5)$ & 0.989 & 0.964 \\
\hline & Larvae (24 h) & $20.1(18.7-23.1)$ & 36.7 (31.7-44.7) & $4.2(1.1)$ & 0.970 & 1 \\
\hline & Larvae (48 h) & $16.3(14.1-18.4)$ & $32.3(26.8-51.8)$ & $3.6(0.8)$ & 0.978 & 1 \\
\hline & Pupae & $67.6(62.0-71.4)$ & 85.4 (78.1-96.5) & $7.4(0.7)$ & 0.970 & 0.384 \\
\hline & ID & $12.5(8.9-15.1)$ & 30.1 (24.9-41.3) & $3.4(0.6)$ & 0.997 & 0.851 \\
\hline & Adult (24 h) & $\begin{array}{c}173.0(163.8- \\
192.0)\end{array}$ & $\begin{array}{c}229.0(212.3- \\
261.1)\end{array}$ & $10.5(2.4)$ & 0.904 & 0.337 \\
\hline & Adult (48 h) & $\begin{array}{c}164.6(156.1- \\
172.1)\end{array}$ & $\begin{array}{c}209.5(196.9- \\
232.2)\end{array}$ & $12.2(1.1)$ & 0.917 & 0.357 \\
\hline
\end{tabular}

$\mathrm{ID}=$ inhibition of development; $\mathrm{h}$ = hours; $\mathrm{SE}=$ standard error; $\mathrm{Cl}$ = confidence interval. IVEO - Illicium verum essential oil. PGEO - Pelargonium graveolens essential oil.

2017; Gomes da Rocha Voris et al., 2018). Li et al. (2013). Wang et al. (2021) suggest that its mechanism of action is through the inhibition of acetylcholinesterase.

The major compounds in $P$. graveolens were citronellol and geraniol, according to the results of Verma et al. (2013). According to Gallardo et al. (2015), the main constituents of geranium essential oil showed insecticidal activity against Musca domestica alone. However, the synergistic effect was not observed when evaluated in combination. It is not known whether the same profile applies to the pulicidal effect. Therefore, studies with the constituents isolated and in association against $C$. felis felis should be encouraged.

The insecticidal activity of crude extract of I. verum fruits has already been reported (Sripongpun, 2008; Szczepanik \& Szumny, 2011; Wei et al., 2014). Its essential oil has insecticidal activity for larvae $\left(\mathrm{LC}_{50}=39.8 \mu \mathrm{g} \cdot \mathrm{mL}^{-1}\right)$ and adults $\left(\mathrm{LC}_{50}=10.3 \mu \mathrm{g} . \mathrm{mg}\right.$.female $\left.{ }^{-1}\right)$ of Aedes aegypti (Gomes da Rocha Voris et al., 2018) and against the insect of importance for grain storage Tribolium confusum $\left(\mathrm{LC}_{50}=552 \mu \mathrm{l.} \mathrm{L}^{-1}\right)$ (Popović et al., 2019). Acaricide activity has also been described for environmental mites Dermatophagoides pteronyssinus $\left(\mathrm{LC}_{50}=0.032 \mu \mathrm{g} \cdot \mathrm{cm}^{-2}\right)$ (Nilprapat et al., 2017) and tick nymph Ixodes ricinus ( $\left(\mathrm{C}_{50}=0.2 \mu \mathrm{l} . \mathrm{cm}^{-2}\right.$ ) (Elmhalli et al., 2018). Added to the results obtained in this study, star anise essential oil demonstrates to be able to act against different classes of arthropods, hematophagous or not, making it promising for the development of an ectoparasiticidal formulation.

Other essential oils have already demonstrated in vitro insecticidal activity against the C. felis felis flea. Essential oils that contain eugenol as their major constituent such as Syzygium aromaticum (Lambert et al., 2020) and Ocimum gratissimum (dos Santos et al., 2020) have low $L C_{50}$ values for adults of $C$. felis felis. regarding the activity against the immature stages, the essential oils of Cinnamomum spp. (Conceição et al., 2020), S. aromaticum (Lambert et al., 2020) and O. gratissimum (dos Santos et al., 2020) demonstrated to be superior to those found in this study. However, it is important to highlight that both essential oils evaluated in this study presented satisfactory insecticidal activity, 

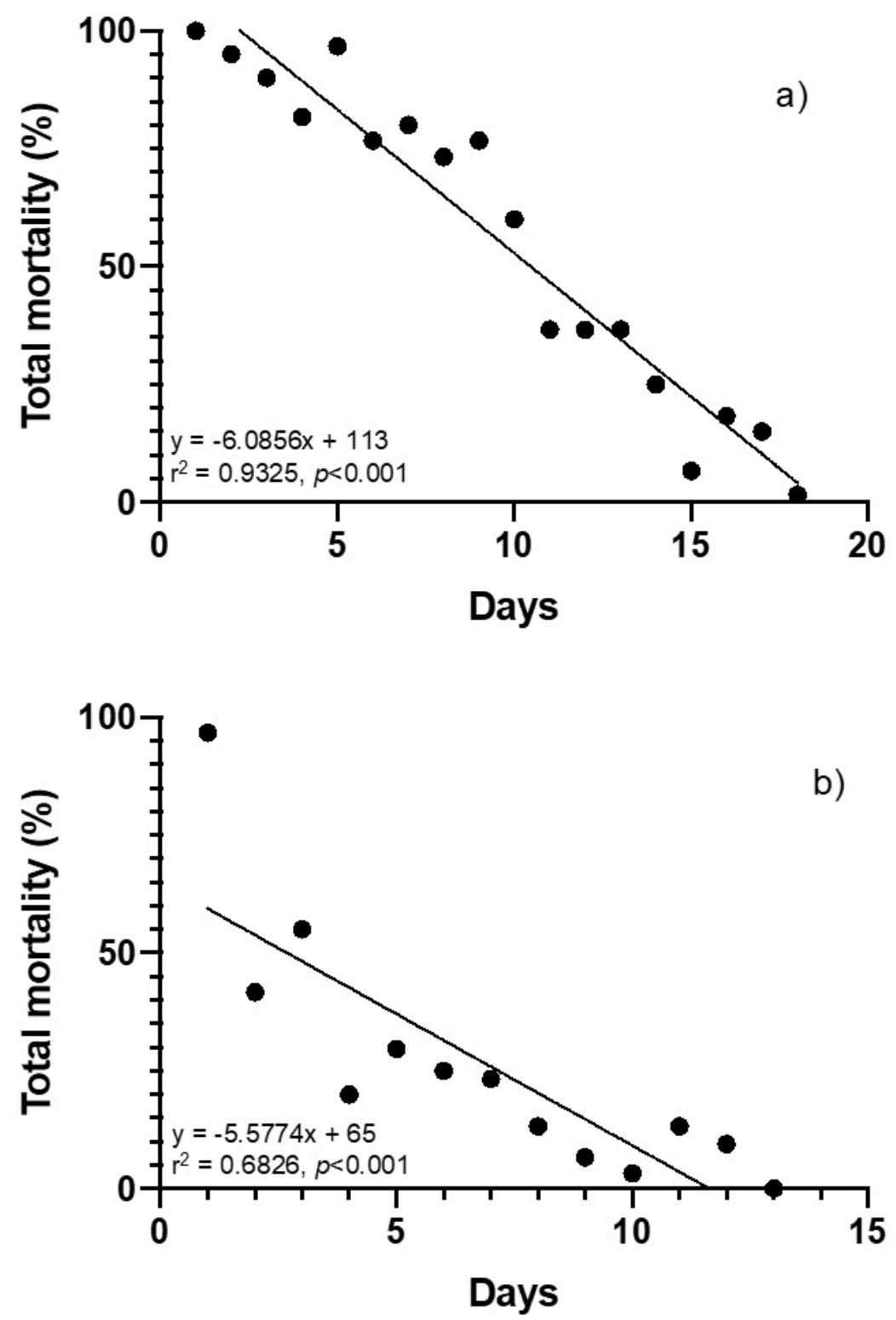

Figure 2. Residual efficacy of essential oils of (a) Illicium verum $\left(800 \mu \mathrm{g} \cdot \mathrm{cm}^{-2}\right)$ and (b) Pelargonium graveolens $\left(240 \mu \mathrm{g} \cdot \mathrm{cm}{ }^{-2}\right)$.

which encourages future studies aiming at their applicability for the control of infestation in animals and in the environment.

We observed mortality of eggs and pupae in the negative control and placebo groups, as well as inhibition of development. According to Rust \& Dryden (1997) and Rust (2005), the total emergence of adults, in C. felis felis, during the biological cycle can vary between $70-100 \%$.

Both essential oils showed the same characteristic of susceptibility against different stages of the cat flea, which is, comparing the $\mathrm{LC}_{90}$ the order of susceptibility was ID $<$ Larva $<$ Egg $<$ Pupae $<$ Adult. The most susceptible was ID because of the essential oil's chronic exposure to all stages. Adults and pupae are the least susceptible and the larval stage most susceptible to ectoparasiticides going as described by Rust (2020).

Star anise is traditionally used as a mosquito repellent and can be used for vector control (Tisgratog et al., 2016). According to the Bio-Pesticides Database (BPDB), use of star anise (70-90\% anethole) is authorized in several countries of the European Union (Lewis et al., 2016), although the threshold of toxicological concern is high (class III). Anethole and estragole, which are the major compounds, are effective against stored grain pests (Bedini et al., 2016) and mites (Shin et al., 2013). 
The major compounds of Pelargonium graveolens were citronellol (29.67\%) and geraniol (14.85\%), which are both monoterpenes. Their chemical structures are similar, so both compounds can contribute to the effect against fleas, especially against eggs $\left(\mathrm{LC}_{50}=20.97 \mu \mathrm{g} \cdot \mathrm{cm}^{-2}\right)$ and for inhibition of development $\left(12.45 \mu \mathrm{g} \cdot \mathrm{cm}^{-2}\right)$. Commercial use of monoterpenes as repellents and insecticides is promising, such as in the product Fulltec ${ }^{\circledR}$, a tick repellent containing 1\% geraniol (Khallaayoune et al., 2009).

The residual effect should be highlighted in relation to development of new biopesticides. In the literature, there are few studies showing the residual effect of essential oils against fleas (Conceição et al., 2020). It is important for EOs to remain active in the environment or on the host after use, to prevent flea reinfestations. Our results showed that the pulicidal activity of the essential oils evaluated remained above $70 \%$ for up to 9 days at a concentration of $800 \mu \mathrm{g} \cdot \mathrm{cm}^{-2}$ of $I$. verum. On the other hand, P. graveolens at $240 \mu \mathrm{g} \cdot \mathrm{cm}^{-2}(100 \%$ mortality of adult stage $)$ only had a residual effect of $41.7 \%$ after 2 days.

The future of biopesticides using essential oils is promising (Pavela \& Benelli, 2016; Mossa, 2016; Raveau et al., 2020). Essential oils have high effectiveness, several mechanisms of action (good for use against resistant insects) and low toxicity, including towards humans. Furthermore, to obtain essential oils is generally relatively simple and cheap, and there is low health risk of intoxication (Pavela \& Benelli, 2016).

As shown, both essential oils were able to eliminate both adult fleas and immature stages, in addition to inhibiting the development of the biological cycle of $C$. felis felis, showing potential for the development of formulations for the control of infestations in animals and also for the environmental control of this insect.

\section{Conclusion}

Use and application of essential oils requires attention to standardization of the product in order to avoid loss of activity. There are several websites that claim effectiveness of the essential oils of these species for tick control, either applied directly on the animal or in collars or in pharmaceutical medicines. The pulicidal activity and residual efficacy of the essential oils of star anise and rose geranium were demonstrated in the present study for the first time. This efficacy is attractive to the pharmaceutical and agronomy industry for development of biopesticides for veterinary medicine, because the essential oils are safe and environmentally friendly.

\section{Acknowledgements}

This study was supported by Fundação de Apoio à Pesquisa Tecnológica da Universidade Federal Rural do Rio de Janeiro (FAPUR) and Coordenação de Aperfeiçoamento Pessoal de Nível Superior (CAPES) code 001.

\section{References}

Abbott WS. A method of computing the effectiveness of an insecticide. 1925. J Am Mosq Control Assoc 1987; 3(2): 302-303. PMid:3333059.

Adams RP. Identification of essential oil components by gas chromatography/mass spectrometry. 4th ed. Carol Stream: Allured Pub Corp; 2007.

Bedini S, Bougherra HH, Flamini G, Cosci F, Belhamel K, Ascrizzi R, et al. Repellency of anethole-and estragole-type fennel essential oils against stored grain pests: the different twins. Bull Insectol 2016; 69(1): 149-157.

Conceição CL, de Morais LAS, Campos DR, Chaves JKO, dos Santos GCM, Cid YP, et al. Evaluation of insecticidal activity of thyme, oregano, and cassia volatile oils on cat flea. Rev Bras Farmacogn 2020; 30(6): 774-779. http://dx.doi.org/10.1007/s43450-020$00111-8$

Dawood MA, El Basuini MF, Zaineldin Al, Yilmaz S, Hasan MT, Ahmadifar E, et al. Antiparasitic and antibacterial functionality of essential oils: an alternative approach for sustainable aquaculture. Pathogens 2021; 10(2): 185. http://dx.doi.org/10.3390/ pathogens10020185. PMid:33572193.

dos Santos JVB, de Almeida Chaves D, De Souza MAA, Riger CJ, Lambert MM, Campos DR, et al. In vitro activity of essential oils against adult and immature stages of Ctenocephalides felis felis. Parasitology 2020; 147(3): 340-347. http://dx.doi.org/10.1017/ S0031182019001641. PMid:31840630.

Elmhalli F, Pålsson K, Örberg J, Grandi G. Acaricidal properties of ylang-ylang oil and star anise oil against nymphs of Ixodes ricinus (Acari: ixodidae). Exp Appl Acarol 2018; 76(2): 209-220. http://dx.doi.org/10.1007/s10493-018-0299-y. PMid:30302625. 
Gallardo A, Picollo MI, Mougabure-Cueto G. Lethal activity of individual and mixed monoterpenoids of geranium essential oil on Musca domestica. Parasitol Res 2015; 114(3): 1229-1232. http://dx.doi.org/10.1007/s00436-015-4315-4. PMid:25604671.

Gomes da Rocha Voris D, Dos Santos Dias L, Alencar Lima J, Dos Santos Cople Lima K, Pereira Lima JB, Dos Santos Lima AL. Evaluation of larvicidal, adulticidal, and anticholinesterase activities of essential oils of Illicium verum Hook. f., Pimenta dioica (L.) Merr., and Myristica fragrans Houtt. against Zika virus vectors. Environ Sci Pollut Res Int 2018; 25(23): 22541-22551. http://dx.doi. org/10.1007/s11356-018-2362-y. PMid:29808407.

Khallaayoune K, Biron JM, Chaoui A, Duvallet G. Efficacy of 1\% geraniol (Fulltec ${ }^{\circledR}$ ) as a tick repellent. Parasite 2009; 16(3): $223-226$. http://dx.doi.org/10.1051/parasite/2009163223. PMid:19839268.

Lambert MM, Campos DR, Borges DA, de Avelar BR, Ferreira TP, Cid YP, et al. Activity of Syzygium aromaticum essential oil and its main constituent eugenol in the inhibition of the development of Ctenocephalides felis felis and the control of adults. Vet Parasitol 2020; 282: 109126. http://dx.doi.org/10.1016/j.vetpar.2020.109126. PMid:32417602.

Lappin MR, Tasker S, Roura X. Role of vector-borne pathogens in the development of fever in cats: 1. Flea-associated diseases. J Feline Med Surg 2020; 22(1): 31-39. http://dx.doi.org/10.1177/1098612X19895941. PMid:31916873.

Lewis KA, Tzilivakis J, Warner DJ, Green A. An international database for pesticide risk assessments and management. Hum Eco Risk Assess: An Int J 2016; 22(4): 1050-1064. http://dx.doi.org/10.1080/10807039.2015.1133242.

Li SG, Li MY, Huang YZ, Hua RM, Lin HF, He YJ, et al. Fumigant activity of Illicium verum fruit extracts and their effects on the acetylcholinesterase and glutathione S-transferase activities in adult Sitophilus zeamais. J Pest Sci 2013; 86(4): 677-683. http:// dx.doi.org/10.1007/s10340-013-0520-z.

Matos LF, Barbosa DRS, Lima EC, Dutra KA, Navarro DMAF, Alves JLR, et al. Chemical composition and insecticidal effect of essential oils from Illicium verum and Eugenia caryophyllus on Callosobruchus maculatus in cowpea. Ind Crops Prod 2020; 145: 112088. http://dx.doi.org/10.1016/j.indcrop.2020.112088.

Mossa ATH. Green pesticides: essential oils as biopesticides in insect-pest management. J Environ Sci Technol 2016; 9(5): 354-378. http://dx.doi.org/10.3923/jest.2016.354.378.

Nilprapat P, Pumnuan J, Insung A. Acaricidal properties of star anise (Illicium verum Hook. f.) essential oil against house dust mite [Dermatophagoides pteronyssinus (Trouessart)]. Int J Agric Technol 2017; 13(7.3): 2307-2315.

Pavela R, Benelli G. Essential oils as ecofriendly biopesticides? Challenges and constraints. Trends Plant Sci 2016; 21(12): 10001007. http://dx.doi.org/10.1016/j.tplants.2016.10.005. PMid:27789158.

Popović A, Petrović M, Stojanović T, Buđen M. The effect of the minth and star anise essential oil on the adults of Tribolium confusum (Coleoptera, Tenebrionidae). Biljni Lek 2019; 47(5): 344-354.

Raveau R, Fontaine J, Lounès-Hadj Sahraoui A. Essential oils as potential alternative biocontrol products against plant pathogens and weeds: a review. Foods 2020; 9(3): 365. http://dx.doi.org/10.3390/foods9030365. PMid:32245234.

Rust MK, Dryden MW. The biology, ecology and management of the cat flea. Annu Rev Entomol 1997; 42(1): 451-473. http://dx.doi. org/10.1146/annurev.ento.42.1.451. PMid:9017899.

Rust MK. Advances in the control of Ctenocephalides felis (cat flea) on cats and dogs. Trends Parasitol 2005; 21(5): 232-236. http:// dx.doi.org/10.1016/j.pt.2005.03.010. PMid:15837612.

Rust MK. Recent advancements in the control of cat fleas. Insects 2020; 11(10): 668. http://dx.doi.org/10.3390/insects11100668. PMid:33003488.

Saraiva LC, de Matos AFIM, Cossetin LF, Couto JCM, dos Santos Petry L, Monteiro SG. Insecticidal and repellent activity of geranium essential oil against Musca domestica and Lucilia cuprina. Int J Trop Insect Sci 2020; 40(4): 1093-1098. http://dx.doi.org/10.1007/ s42690-020-00137-4.

Shin E-H, Song BG, II Lee H, Park MY, Ahn Y-J, Chang K-S. Repellency of cassia bark, eucalyptus, and star anise oils and their major constituents to Leptotrombidium pallidum (Acari: trombiculidae). J Med Entomol 2013; 50(3): 579-584. http://dx.doi.org/10.1603/ ME12129. PMid:23802452.

Sripongpun G. Contact toxicity of the crude extract of Chinese star anise fruits to house fly larvae and their development. Songklanakarin J Sci Technol 2008; 30(5): 667-672.

Streicher M. Flea allergy dermatitis. In: Horne K, Schwassmann M, Logas D, editors. Small animal dermatology for technicians and nurses. Hoboken: Wiley-Blackwell; 2019. p. 85-101. http://dx.doi.org/10.1002/9781119108641.ch6

Szczepanik M, Szumny A. Insecticidal activity of star anise (Illicum verum Hook. F.) fruits extracts against lesser mealworm, Alphitobius diaperinus Panzer (Coleoptera: tenebrionidae). Allelopathy J 2011; 27(2): 277-288. 
Tisgratog R, Sanguanpong U, Grieco JP, Ngoen-Kluan R, Chareonviriyaphap T. Plants traditionally used as mosquito repellents and the implication for their use in vector control. Acta Trop 2016; 157: 136-144. http://dx.doi.org/10.1016/j.actatropica.2016.01.024. PMid:26826392.

van Den Dool H, Kratz PD. A generalization of the retention index system including linear temperature programmed gas-liquid partition chromatography.J Chromatogr 1963; 11: 463-471. http://dx.doi.org/10.1016/S0021-9673(01)80947-X. PMid:14062605.

Verma RS, Rahman L, Verma RK, Chauhan A, Singh A. Essential oil composition of Pelargonium graveolens L'Her ex Ait. cultivars harvested in different seasons. J Essent Oil Res 2013; 25(5): 372-379. http://dx.doi.org/10.1080/10412905.2013.782476.

Wang Z, Xie Y, Sabier M, Zhang T, Deng J, Song X, et al. Trans-anethole is a potent toxic fumigant that partially inhibits rusty grain beetle (Cryptolestes ferrugineus) acetylcholinesterase activity. Ind Crops Prod 2021; 161: 113207. http://dx.doi.org/10.1016/j. indcrop.2020.113207.

Wei L, Hua R, Li M, Huang Y, Li S, He Y, et al. Chemical composition and biological activity of star anise Illicium verum extracts against maize weevil, Sitophilus zeamais adults. J Insect Sci 2014; 14: 80. http://dx.doi.org/10.1093/jis/14.1.80. PMid:25368036.

Yu CY, Zhang JF, Wang T. Star anise essential oil: chemical compounds, antifungal and antioxidant activities: a review. J Essent Oil Res 2021; 33(1): 1-22. http://dx.doi.org/10.1080/10412905.2020.1813213. 